\title{
Pemanfaatan Teknologi Digital Wallet sebagai Solusi Alternatif Pembayaran Modern: Literature Review
}

\author{
Jihan Fadhilah ${ }^{1 *}$, Cut Aja Anis Layyinna ${ }^{2}$, Rijal Khatami ${ }^{3}$, Fitroh $^{4}$ \\ ${ }^{1}$ Universitas Islam Negeri Syarif Hidayatullah Jakarta, Jl. Ir. H. Juanda No. 95, Kec. Ciputat Timur, Kota Tangerang \\ Selatan, Banten 15412, Indonesia \\ 1jihan.fadhilah6@gmail.com*; ${ }^{2}$ cutajaanislayyinna@gmail.com; ${ }^{3}$ khatami.rijal@gmail.com; ${ }^{4}$ fitroh@ uinjk.ac.id \\ * corresponding author
}

\section{N F O A R T I K E L}

Sejarah Artikel:

Diterima 06 Juni 2021

Diperbaiki 20 Juni 2021

Diterima 08 Juli 2021

Diterbitkan 14 Agustus 2021

\section{Keywords:}

Digital Wallet

Alternative Payment

Financial Technology Innovation

Online Transaction

\section{Kata Kunci:}

Dompet Digital

Pembayaran Alternatif

Inovasi Teknologi Keuangan

Transaksi Online

Korespondensi:

Telepon: +62 81310950850

E-mail: jihan.fadhilah6@gmail.com

\begin{abstract}
Financial technology innovation in the form of digital wallets is very interesting to the public. The efficiency offered from this payment system makes people start to switch from conventional payments to digital payments. In addition, many other factors influence multi-generational people using digital wallets as an alternative to their daily payments. The use of digital wallets is currently widely applied to online transportation transactions, purchases in e-commerce, to food and beverage delivery services. The method used in this study is a method of literature study with the goals to find out the development of digital wallet usage in the community from various journals sourced from Scopus and several websites that have been analyzed and processed by researchers into a literature review study. From the results obtained, it can be concluded that from year to year there is an increase in the number of digital wallet users, especially in Indonesia. Moreover after the Covid-19 pandemic, the number of digital wallet users is increasing because people have to avoid physical contact so that more transactions with digitally.
\end{abstract}

\section{ABSTRAK}

Inovasi teknologi keuangan berupa digital wallet sangat manarik perhatian masyarakat. Efisiensi yang ditawarkan dari sistem pembayaran ini membuat masyarakat mulai beralih dari pembayaran konvensional ke pembayaran digital. Selain itu banyak faktor lain yang mempengaruhi para multi generasi menggunakan digital wallet sebagai alternatif pembayaran sehari-hari mereka. Penggunaan digital wallet saat ini banyak diterapkan untuk transaksi transportasi online, pembelian di e-commerce, hingga jasa pesan antar makanan dan minuman. Metode yang digunakan pada penelitian ini yaitu metode studi literatur dengan tujuan untuk mengetahui perkembangan penggunaan digital wallet di masyarakat dari berbagai jurnal yang bersumber dari Scopus dan beberapa website yang telah dianalisis dan diolah peneliti menjadi sebuah kajian literature review. Dari hasil yang didapatkan dapat disimpulkan bahwa dari tahun ke tahun terjadi peningkatan jumlah pengguna digital wallet, khususnya di Indonesia. Apalagi setelah pandemi Covid-19, jumlah pengguna digital wallet semakin meningkat karena masyarakat harus menghindari kontak fisik sehingga lebih banyak melakukan transaksi secara digital.

\section{Pendahuluan}

Dunia teknologi semakin berkembang pesat dari tahun ke tahun. Tidak dapat dipungkiri bahwa kemajuan teknologi membawa banyak perubahan dunia. Salah satu perubahan di bidang keuangan yang disebabkan oleh kecanggihan teknologi adalah metode pembayaran online. Metode pembayaran online menggunakan digital wallet merupakan salah satu inovasi teknologi di bidang keuangan yang sedang ramai diperbincangkan. Digital wallet adalah suatu layanan elektronik yang berfungsi untuk instrumen pembayaran atau alat pembayaran dengan menggunakan kartu dan juga uang elektronik. Menurut [1] saat ini orang lebih suka melakukan transaksi perbelanjaan online karena dapat lebih efisien waktu dan sistem dapat menyimpan informasi dengan aman. Berdasarkan jurnal [2], sistem pembayaran individu (konvensional) saat ini sudah mulai tergantikan dengan sistem 
digital wallet. Penyebaran sistem baru ini tergantung juga pada aspek keamanan, kemudahan fungsionalitas penggunaan dan efektivitas realisasi.

Di Indonesia, saat ini sudah banyak generasi yang mulai menggunakan digital wallet sebagai alternatif solusi pembayaran mereka. Menurut penelitian [3] dompet digital di Indonesia mengalami perkembangan pesat dalam 5 tahun terakhir. Dengan data penelitian dari [4] saat ini ada 38 dompet digital di Indonesia dengan lisensi resmi dari Bank Indonesia, antara lain Gopay, OVO, LinkAja, dan Dana. Di Q2 2019, Gopay adalah dompet digital Gojek dengan pengguna paling aktif di Indonesia. Penggunaan dompet digital di Indonesia diperkirakan mencapai 15 miliar USD pada tahun 2020.

Tetapi walaupun telah mengalami perkembangan, berdasarkan penelitian [5], hanya $3 \%$ penduduk Indonesia berusia di atas 15 tahun yang menggunakan layanan digital wallet pada tahun 2017. Masalah yang menghambat terciptanya cashless society menurut [6] adalah karena masalah kurangnya kesadaran dan pengetahuan, takut melakukan pembayaran online dan masalah keamanan akan produk digital wallet tersebut.

Beberapa penelitian terdahulu sudah dilakukan, misalnya seperti penelitian [7] yang menyebutkan bahwa ada keterkaitan erat antara penggunaan moda transportasi online dengan pembayaran digital dimana berdasarkan 251 siswa yang dijadikan responden, hampir semua nya merespon positif atas jaringan transportasi online yang dilengkapi dengan digital wallet. Selain itu juga, telah dilakukan penelitian [8] mengenai transaksi e-commerce, seperti digital wallet, e-cash, ataupun pembayaran offline menggunakan TPM sebagai teknologi canggih yang membantu memudahkan proses pembayaran nya.

Oleh karena itu, pada literature review ini pembahasan akan difokuskan mengenai masalah transaksi menggunakan digital wallet sebagai solusi alternatif pembayaran modern saat ini dengan tujuan untuk melihat dari berbagai sumber literatur terdahulu mengenai penggunaan digital yang telah digunakan oleh masyarakat serta menganalisa beberapa faktor yang mempengaruhi masyarakat untuk beralih menggunakan sistem pembayaran digital tersebut.

\section{Metode}

Metode penelitian yang digunakan pada literature review ini adalah studi literatur. Menurut [9] metode studi literatur adalah serangkaian kegiatan yang berkenaan dengan metode pengumpulan dari berbagai data pustaka, seperti jurnal, buku, website ataupun sumber lainnya, kemudian membaca dan mencatat serta melakukan pengolahan bahan penelitian terkait. Menurut [10] menyatakan bahwa studi literatur adalah sebuah metode yang dilakukan dengan menelaah secara tekun akan kepustakaan yang diperlukan dalam penelitian.

Dengan metode studi literatur, ada beberapa langkah yang dilakukan peneliti dalam menganalisa dan mendapatkan data kepustakaan sesuai dengan penelitian yang dilakukan. Langkah pertama yaitu, peneliti menggunakan alat bantu atau tools, yaitu Publish or Perish 7. Publish or Perish adalah sebuah software program yang digunakan untuk menganalisa dan mendapatkan kembali sitasi akademik dari beberapa sumber seperti, Google Scholar, Scopus, Microsoft Academic Search, dll [11]. Dalam penelitian ini, penelitia mencari paper yang mengandung judul "Digital Wallet" dari sumber Scopus dan didapatkan 58 paper yang seluruhnya merupakan Journal Article terkait.

Langkah kedua, yaitu data dari Publish or Perish 7 disimpan dalam format .ris (RIS/Ref Manager) dan kemudian di import kedalam Mendeley untuk mendapatkan rincian paper tersebut. Mendeley adalah sebuah perangkat lunak yang digunakan untuk mengintegrasikan "citation \& reference 
manager" ke dalam sebuah jejaring sosial. Dengan jejaring semacam ini, peneliti di berbagai belahan dunia dapat berkolaborasi dan melakukan sharing data penelitian [12]. Setelah melakukan import, jangan lupa untuk melakukan sinkronisasi di Mendeley agar metadata dari 58 jurnal tersebut dapat otomatis diperbaharui.

Langkah ketiga, yaitu menyimpan data yang telah disinkronkan di Mendeley ke dalam format .xml (EndNote XML) agar dapat dibuka di Microsoft Excel. Setelah data di import ke Microsoft Excel, peneliti melakukan penyaringan data dengan menyesuaikan topik penelitian. Karena sumber data berasal dari Scopus, peneliti melakukan penyaringan data dengan bantuan masterscopus, artinya jurnal yang dikenali adalah jurnal yang telah terindeks Scopus. Data masterscopus [13] di import dalam sheet yang berbeda di file Microsoft Excel yang sama dengan data Mendeley sebelumnya.

Langkah keempat adalah penyaringan dengan master Scopus. Dalam tahap ini jurnal-jurnal yang terindeks maupun tidak terindeks Scopus dibagi dalam 4 Kuartil (Q-ranking of journal) dimana Q1 merupakan ranking tertinggi dan Q4 adalah ranking terendah. Kuartil ini adalah kategori jurnal ilmiah yang mewakili tingkat kutipan yang diidentifikasi oleh indikator scientometric. Jadi, publikasi berkisar dari yang paling direferensikan. Dari 58 jurnal yang didapatkan, untuk Q1 dan Q2 masingmasing hanya berjumlah 5 jurnal dan 1 jurnal. Oleh karena itu, peneliti memutuskan untuk melakukan penyaringan lanjutan agar didapatkan referensi yang sesuai dengan topik penelitian yang dibahas.

Dapat dilihat dalam Gambar 1 merupakan hasil penyaringan data dengan masterscopus yang sudah terbagi dalam Q1-Q4, dan ada 35 jurnal yang tidak terindeks Scopus.

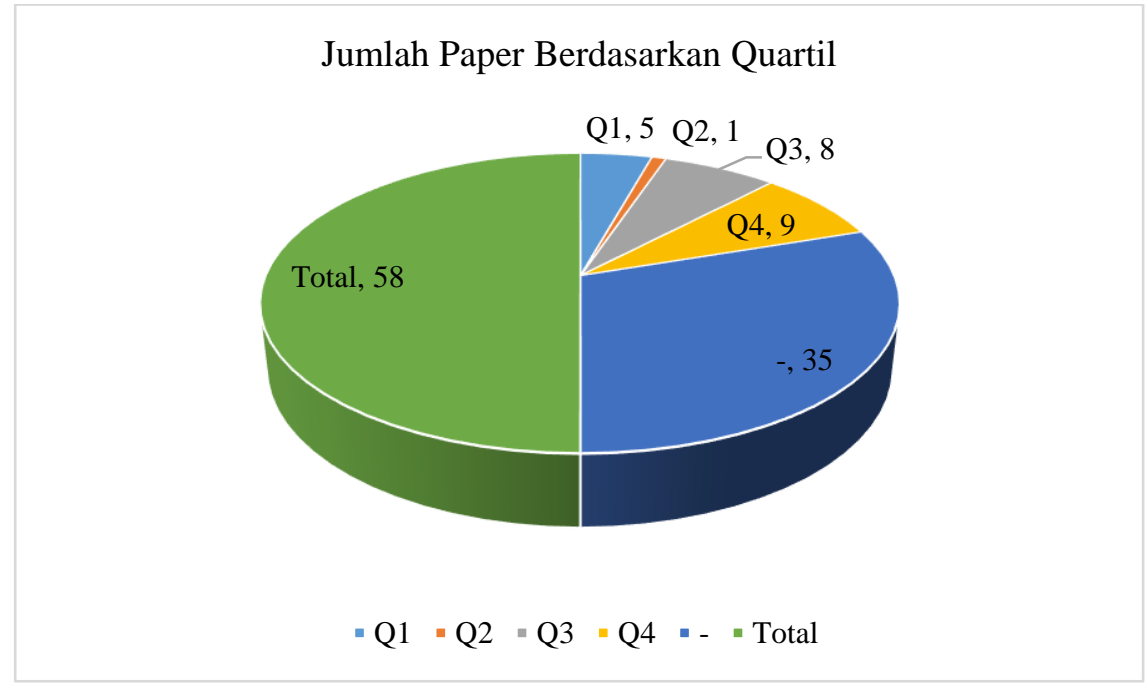

Gambar 1. Klasifikasi Jurnal Berdasarkan Quartile Master Scopus

Langkah kelima adalah penyaringan lanjutan berdasarkan tahun terbit. Dalam Gambar 2, dapat terlihat rincian jumlah jurnal yang diterbitkan di Scopus berdasarkan tahun terbit nya seperti berikut. 


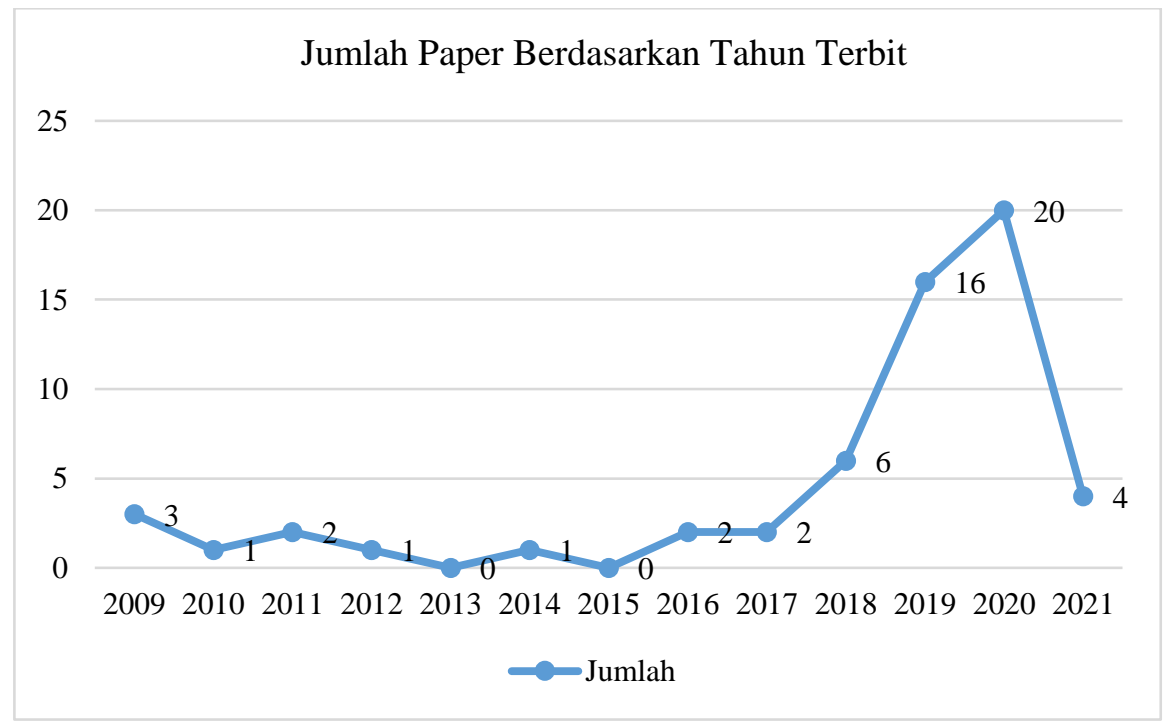

Gambar 2. Klasifikasi Jurnal Berdasarkan Tahun Terbit

Setelah dilakukan penyaringan data berdasarkan tahun penerbitan, peneliti memutuskan untuk mengambil referensi dari seluruh penelitian dari tahun 2009-2021, tetapi tetap dengan memperhatikan isi dari topik penelitian tersebut. Peneliti membaca dan mengambil poin dari setiap abstrak jurnal terpilih untuk penyusunan isi topik penelitian. Kemudian peneliti juga mengambil data penelitian dari berbagai website yang memuat informasi terkait penggunaan digital wallet.

\section{Hasil dan Pembahasan}

\subsection{Teknologi Inovatif di Bidang Keuangan}

Perkembangan zaman pasti selalu diikuti dengan perkembangan teknologi yang semakin canggih. Banyak penemuan-penemuan baru di dunia teknologi yang menjadi inovasi baru lahirnya sebuah perubahan budaya bahkan perilaku di masyarakat. Salah satu contoh inovasi teknologi yang sedang ramai diperbincangkan di dunia keuangan adalah Digital wallet [14]. Digital wallet atau yang biasa disebut dompet digital adalah sebuah bentuk dari uang elektronik yang berbasis server. Digital wallet telah mengalami perkembangan yang sangat pesat dalam 5 tahun terakhir [3]. Banyak penelitian yang mulai membahas tentang digital wallet 5 tahun terakhir ini. Sebenarnya istilah Digital wallet sendiri bukan sebuah istilah baru di dunia teknologi keuangan, istilah ini sudah mulai terdengar sejak akhir tahun 2000-an [15]. Tetapi manfaat dan pentingnya teknologi ini baru mendapat perhatian lebih setelah ponsel dan internet mengalami perkembangan yang sangat pesat [6]. Seperti yang terjadi di beberapa negara di dunia, banyak penelitian yang telah dilakukan di beberapa negara terkait penggunaan digital wallet di negara tersebut, seperti terlihat pada Tabel 1 berikut.

Tabel 1. Penelitian di Beberapa Negara Terkait Digital Wallet

\begin{tabular}{ll}
\multicolumn{1}{c}{ Negara } & \multicolumn{1}{c}{ Penelitian Terkait } \\
\hline Cina & {$[16]$} \\
India & {$[17],[6],[18],[19],[20],[21],[22],[23]$} \\
Arab Saudi & {$[16]$} \\
Indonesia & {$[5],[24],[25],[26],[27]$}
\end{tabular}

Negara-negara tersebut perlahan sudah mulai menggunakan digital wallet sebagai metode pembayaran untuk transaksi pembayaran sehari-hari mereka. 


\subsection{Perkembangan Digital Wallet}

Perkembangan metode pembayaran non tunai mulai mengalami peningkatan yang signifikan pada tahun 2007 hingga 2011 [28]. Dan perkembangan itu terus mengalami peningkatan hingga saat ini, bahkan dalam 5 tahun terakhir ini banyak sekali penelitian yang membahas terkait hal tersebut. Penyebab semakin cepat nya peningkatan jumlah pengguna yang menggunakan digital wallet adalah karena kemajuan teknologi yang semakin canggih dari tahun ke tahun [29]. Teknologi memfasilitasi keinginan manusia yang ingin serba cepat dan mudah. Digital wallet menjadi salah satu teknologi yang mulai digunakan oleh masyarakat umum dari berbagai generasi [3].

Berdasarkan beberapa penelitian terkait, menyatakan bahwa seluruh dunia saling berlomba untuk meningkatkan efisiensi pekerjaan manusia dengan bantuan teknologi dan internet, hal itulah yang menjadi salah satu faktor pemicu peralihan konsumen dari tradisional ke digitalisasi [30]. Selain mempercepat proses transaksi, digital wallet sebagai teknologi inovatif yang berbasis server juga membantu pengguna untuk menyimpan data transaksi mereka tanpa perlu mencatat secara manual mengenai pengeluaran sehari-hari mereka [31]. Karena perkembangan sistem elektronik berbasis internet semakin canggih tiap tahun nya, maka berdasarkan penelitian yang dilakukan [29] didapatkan hasil bahwa penggunaan digital wallet akan terus meningkat sehingga diharapkan bagi negara-negara di dunia untuk beralih dari kegiatan transaksi keuangan konvensional ke transaksi elektronik.

\subsection{Penggunaan Digital Wallet di Indonesia}

Indonesia sedang menikmati masa bonus demografi yang sangat menguntungkan, dimana jumlah penduduk usia produktif lebih banyak daripada usia non produktif yaitu lebih dari $68 \%$ dari total populasi [32]. Menurut data dari Badan Pusat Statistik Indonesia, berdasarkan hasil sensus penduduk tahun 2020 (SP2020) yang dilakukan hingga September 2020 mencatat bahwa jumlah penduduk Indonesia sebesar 270,20 juta jiwa dimana jumlah ini mengalami kenaikan sebanyak 32,56 juta jiwa dibandingkan dengan hasil SP2010. Tetapi, dikatakan juga bahwa laju pertumbuhan penduduk periode tahun 2010-2020 memiliki rata-rata sebesar 1,25\%, melambat jika dibandingkan dengan periode 2000-2010 yang sebesar 1,49\% [33].

Dengan bonus demografi yang sangat besar, jumlah pengguna digital wallet di Indonesia mengalami peningkatan yang sangat signifikan juga. Pengguna digital wallet di Indonesia berasal dari berbagai generasi, mulai dari generasi X, Y, hingga generasi Z. Generasi X adalah mereka yang lahir diantara tahun 1965 dan 1980, mereka awalnya belum mengenal komputer hingga akhirnya menggunakaan komputer di awal keluaran nya. Generasi Y atau yang disebut dengan millenials adalah mereka yang lahir diantara tahun 1980 hingga awal 2000 an. Mereka sudah mengenal dan menggunakan teknologi dengan lebih luas, mereka juga mengalami beberapa perubahan teknologi dan era globalisasi. Sedangkan generasi $\mathrm{Z}$ adalah generasi yang lahir setelah tahun 1995 dan dapat dikatakan generasi yang sangat mengenal teknologi bahkan semenjak mereka lahir [34].

Berdasarkan penelitian [5], walaupun digital wallet telah mendapat perhatian sebagai sistem pembayaran alternatif di Indonesia, namun berdasarkan data Bank Dunia pada tahun 2017, hanya $3 \%$ penduduk Indonesia yang berusia diatas 15 tahun yang menggunakan layanan digital wallet. Tetapi, setelah tahun 2017, transaksi uang elektronik di Indonesia mengalami peningkatan yang sangat pesat. Berdasarkan data dari Bank Indonesia (BI) ditemukan bahwa volume transaksi uang elektronik pada akhir tahun 2018 melonjak 209,8\% menjadi 2.9 miliar transaksi, dibandingkan tahun 2017 sebesar 943.3 juta transaksi. Dan pada Juli 2019, volume transaksi uang elektronik telah mencapai 2,7 miliar atau mendekati angka pada akhir tahun 2018 [35]. 
Dikutip dari [36] bahwa pada tahun 2014, pemerintah telah mencanangkan program GNNT (Gerakan Nasional Non Tunai) untuk meningkatkan penggunaan uang digital di Indonesia. Gubernur Bank Indonesia periode 2013-2018, Agus D.W. Martowaedojo mengatakan bahwa GNNT bertujuan untuk meningkatkan kesadaran masyarakat menggunakan instrumen non tunai dan mencintakan cashless society khususnya dalam melakukan transaksi ekonomi nya. Dikutip dari CNBC Indonesia, Deputi Gubernur Senior Bank Indonesia 2013, Mirza Adityaswara juga mengatakan bahwa secepatnya bank sentral akan mendorong masyarakat untuk menggunakan model transaksi non tunai [37].

Berdasarkan data yang bersumber resmi dari [38] upaya Bank Indonesia untuk menciptakan cashless society di Indonesia membuahkan hasil. Dilihat pada Tabel 2 mengenai peredaran jumlah uang elektronik di Indonesia 5 tahun terakhir sebagai berikut.

Tabel 2. Jumlah Peredaran Uang Elektronik di Indonesia

\begin{tabular}{ll}
\hline \multicolumn{1}{c}{ Tahun } & \multicolumn{1}{c}{ Jumlah Instrumen } \\
\hline 2016 & 51.204 .580 \\
2107 & 90.003 .848 \\
2018 & 167.205 .578 \\
2019 & 292.299 .320 \\
2020 & 432.281 .380 \\
2021 (per Mei 2021) & 498.202 .416 \\
\hline
\end{tabular}

Penggunaan digital wallet di Indonesia untuk generasi millenials dan generasi Z lebih banyak digunakan untuk kebutuhan transaksi pembayaran untuk transportasi dan jasa pesan antar makanan minuman online. Untuk penggunaan sebagai metode pembayaran transportasi online, [7] melakukan penelitian dengan penyebaran kuisioner kepada 336 siswa dan diambil data dari 251 siswa menengah atas pengguna transportasi online GO-JEK dan GRAB karena mereka memiliki digital wallet yaitu GO-PAY dan GRAB-PAY. Hasilnya adalah dari total 251 siswa menengah atas menyatakan nyaman dan aman dengan menggunakan digital wallet sebagai metode pembayaran nya.

Selama masa pandemi Covid-19 juga penggunaan terhadap digital wallet mengalami kemajuan yang sangat pesat karena di dukung oleh pemerintah Indonesia yang ikut membantu sosialisasi dan penerapan digital wallet di bidang penyaluran dana Program Kartu Prakerja. Program Kartu Prakerja adalah program penyaluran dana bantuan dan peningkatan skill bagi para masyarakat yang terkena dampak dari pandemi Covid-19 sejak tahun 2020 lalu. Dikutip dari [39], menurut data dari pemerintah ada sebanyak 5,9 juta peserta dari program kartu prakerja yang disalurkan dana bantuan oleh pemerintah melalui dompet digital, seperti OVO, LinkAja, dan GOPAY. Berdasarkan [40], persentase bisnis digital wallet di Indonesia juga mengalami peningkatan yang sangat signifikan, dari 7\% di tahun 2018 menjadi 22\% di tahun 2019.

\subsection{Faktor yang Memengaruhi Penggunaan Digital Wallet}

Perkembangan pesat penggunaan digital wallet tidak terlepas dari beberapa faktor yang membuat masyarakat sadar untuk beralih ke metode pembayaran digital. Kesadaran masyarakat didasarkan pada kebutuhan individu akan metode pembayaran yang lebih efisien dan praktis. Menurut penelitian [41] ada beberapa faktor yang mempengaruhi penggunaan digital wallet antar generasi. Dari data penelitian tersebut didapatkan hasil bahwa faktor yang mempengaruhi para generasi $\mathrm{X}$, yaitu kemudahan penggunaan yang dirasakan, kegunaan yang dirasakan, kompatibilitas, dan kepercayaan secara positif mempengaruhi niat untuk digunakan. Sedangkan faktor-faktor yang mempengaruhi 
niat untuk digunakan pada generasi $\mathrm{Y}$ adalah kegunaan yang dirasakan, kontrol perilaku yang dirasakan, dan kepercayaan. Dan faktor-faktor yang mempengaruhi niat untuk digunakan pada generasi $\mathrm{Z}$ adalah kemudahan penggunaan yang dirasakan, dan kegunaan yang dirasakan. pada akhirnya, berdasarkan data setiap generasi, niat untuk menggunakan secara tidak langsung mempengaruhi penggunaan aktual, kepuasan yang dirasakan, dan rekomendasi untuk digunakan. Perbedaan faktor yang terjadi disebabkan oleh kebutuhan dan persepsi yang berbeda antar generasi.

Kenyamanan, fleksibilitas, dan manfaat bagi konsumen adalah kunci untuk penerimaan dan keberhasilan teknologi baru [42]. Dalam penelitian lain, faktor seperti kemudahan penggunaan, keamanan, kredibilitas, dan penawaran untuk memiliki diskusi yang lebih spesifik menjadi faktor GOPAY yang dibuat GOJEK mempengaruhi konsumen untuk menggunakan digital wallet tersebut sebagai alat pembayaran dalam transaksi nya [26]. Temuan penelitian lain menunjukkan bahwa harapan kinerja, pengaruh sosial, kondisi fasilitasi, motivasi hedonik dan kepercayaan mempengaruhi niat perilaku dompet digital dan harapan usaha tidak mempengaruhi niat perilaku dompet digital. Selain itu, ada faktor eksternal pengguna dan mempertimbangkan lokasi setiap pengguna, dalam konteks penelitian ini penggunaan dompet digital berbasis aplikasi lebih sering digunakan untuk belanja kuliner [43].

Faktor penerimaan tertinggi yang didapat dari penelitian lain adalah kemudahan penggunaan, kemudian kecepatan adalah faktor penerimaan peringkat teratas konsumen dalam menggunakan layanan digital wallet, sementara biaya-manfaat adalah faktor kedua penerimaan uang tunai digital. Temuan ini dapat memungkinkan penyedia produk untuk meningkatkan strategi pemasaran mereka yang lebih baik, dengan meningkatkan produk mereka terkait kemudahan penggunaan, kecepatan, dan biayanya [24].

\section{Kesimpulan}

Digital wallet adalah sebuah teknologi uang elektronik berbasis server dimana dapat menyimpan informasi diri dan transaksi secara otomatis. Berdasarkan beberapa penelitian terkait, penggunaan digital wallet merupakan hasil dari perkembangan teknologi keuangan yang semakin canggih. Ponsel dan internet merupakan teknologi yang berperan penting dalam penigkatan signifikan yang terjadi terhadap transaksi digital wallet. Penggunaan digital wallet masih didominasi untuk melakukan pembayaran transaksi transportasi online, pembelian melalui e-commerce, dan jasa pesan antar makanan minuman. Banyak faktor yang mempengaruhi masyarakat melakukan peralihan transaksi dari konvensional ke digital, diantaranya yaitu: kemudahaan penggunaan, keamanan, kecepatan, kredibilitas, faktor kepercayaan, dan biaya manfaat dari produk digital wallet tersebut.

\section{Daftar Pustaka}

[1] P. Tiwari, V. Garg, and A. Singhal, "A study of consumer adoption of digital wallet special reference to NCR," Proceedings of the 9th International Conference On Cloud Computing, Data Science and Engineering, Confluence 2019. pp. 664-669, 2019, doi: 10.1109/CONFLUENCE.2019.8776939.

[2] R. Raghavendra, M. Niranjanamurthy, M. N. Nachappa, and K. B. Shalini, "An emphasis of digital wallets for E-commerce transactions,” J. Comput. Theor. Nanosci., vol. 16, no. 9, pp. 3748-3753, 2019, doi: $10.1166 / j c t n .2019 .8244$.

[3] Arindy and A. Suzianti, "Developing Digital Wallet Services in Indonesia: A Multigeneration Perspective," ACM Int. Conf. Proceeding Ser., 2020, doi: 10.1145/3429789.3429811.

[4] A. F. Fainusa, R. Nurcahyo, and M. Dachyar, "Conceptual Framework for Digital Wallet User Satisfaction," ICETAS 2019 - 2019 6th IEEE International Conference on Engineering, Technologies and Applied Sciences. 2019, doi: 10.1109/ICETAS48360.2019.9117285.

[5] M. Widodo, M. I. Irawan, and R. A. Sukmono, "Extending UTAUT2 to explore digital wallet adoption in Indonesia," 2019 International Conference on Information and Communications Technology, ICOIACT 2019. pp. 878-883, 2019, doi: 10.1109/ICOIACT46704.2019.8938415. 
[6] S. P. Mathiraj, S. D. T. Geeta, and R. Saroja Devi, "Consumer acuity on select digital wallets," Int. J. Sci. Technol. Res., vol. 8, no. 12, pp. 3551-3556, 2019, [Online]. Available: https://api.elsevier.com/content/abstract/scopus_id/85077200469.

[7] Y. U. Chandra, Meyliana, and M. Jhonsons, "Analysis of digital wallet for higher education student using online transportation network services," Proceedings of 2020 International Conference on Information Management and Technology, ICIMTech 2020. pp. 1-5, 2020, doi: 10.1109/ICIMTech50083.2020.9211108.

[8] W. M. Binmahfooz and A. Alattar, "Proposed modifications to the digital wallets mechanism," IMSCI 2009 - 3rd International Multi-Conference on Society, Cybernetics and Informatics, Proceedings, vol. 2. pp. 46-51, 2009, [Online]. Available: https://api.elsevier.com/content/abstract/scopus_id/84896685279.

[9] M. Zed, Metode Penelitian Kepustakaan. Jakarta: Yayasan Pustaka Obor Indonesia, 2014.

[10] M. Nazir and R. Sikmumbang, Metode Penelitian. Bogor: Ghalia Indonesia, 2009.

[11] A.-W. Harzing, "About Publish or Perish," 2016. https://harzing.com/resources/publish-or-perish (accessed Jun. 18, 2021).

[12] H. Supriyanto, "Pengantar \& Instalasi Mendeley." http://lib.ugm.ac.id/ind/?page_id=336.

[13] Scimago, "Journal Rankings on Scopus," 2021. https://www.scimagojr.com/journalrank.php (accessed Jun. 18, 2021).

[14] M. A. Hassan and Z. Shukur, "Review of Digital Wallet Requirements," 2019 International Conference on Cybersecurity, ICoCSec 2019. pp. 43-48, 2019, doi: 10.1109/ICoCSec47621.2019.8970996.

[15] I. Aldrich, High-Frequency Trading: A Practical Guide to Algorithmic Strategies and Trading System, Second edi. New York: John Wiley and Sons, 2013.

[16] A. Almuhammadi, "An overview of mobile payments, fintech, and digital wallet in Saudi Arabia," Proceedings of the 7th International Conference on Computing for Sustainable Global Development, INDIACom 2020. pp. 271-278, 2020, doi: 10.23919/INDIACom49435.2020.9083726.

[17] H. Aparna, S. Karthika, and V. R. Rajalakshmi, "A study on the digital wallet usage among citizens of Kochi using FP-growth algorithm,” Int. J. Recent Technol. Eng., vol. 7, no. 6, pp. 1315-1322, 2019, [Online]. Available: https://api.elsevier.com/content/abstract/scopus_id/85067073663.

[18] T. Joshi, S. S. Gupta, and N. Rangaswamy, "Digital Wallets \&\#x2018;Turning a Corner\&\#x2019; for Financial Inclusion: A Study of Everyday PayTM Practices in India," IFIP Advances in Information and Communication Technology, vol. 552. pp. 280-293, 2019, doi: 10.1007/978-3-030-19115-3_23.

[19] R. Seranmadevi, D. David Winster Praveenraj, and M. Latha Natarajan, "E-wallet - A technological revolution in digital India," Int. J. Innov. Technol. Explor. Eng., vol. 8, no. 11, pp. 3870-3877, 2019, doi: 10.35940/ijitee.I8932.0981119.

[20] R. K. Bagla and V. Sancheti, "Gaps in customer satisfaction with digital wallets: challenge for sustainability," J. Manag. Dev., vol. 37, no. 6, pp. 442-451, 2018, doi: 10.1108/JMD-04-2017-0144.

[21] P. Maindola, N. Singhal, and A. D. Dubey, "Sentiment Analysis of Digital Wallets and UPI Systems in India Post Demonetization Using IBM Watson," 2018 International Conference on Computer Communication and Informatics, ICCCI 2018. 2018, doi: 10.1109/ICCCI.2018.8441441.

[22] R. K. Singhal, P. Chauhan, and T. R. Pandey, "Exploration of Factors Affecting Adoption of Digital Wallet among Indian Domestic Tourist: Study of Trust and Security Perception," ICRITO 2020 - IEEE 8th International Conference on Reliability, Infocom Technologies and Optimization (Trends and Future Directions). pp. 1268-1271, 2020, doi: 10.1109/ICRITO48877.2020.9197917.

[23] P. Chaddha, B. Agarwal, and A. Zareen, "Investigating the effect of the credibility of celebrity endorsement on the intent of consumers to buy digital wallets in India," Indian J. Econ. Bus., vol. 20, no. 1, pp. 63-79, 2021, [Online]. Available: https://api.elsevier.com/content/abstract/scopus_id/85103127610.

[24] M. Nabila, B. Purwandari, B. A. A. Nazief, D. A. Chalid, S. S. Wibowo, and I. Solichah, "Financial Technology Acceptance Factors of Electronic Wallet and Digital Cash in Indonesia," 2018 International Conference on Information Technology Systems and Innovation, ICITSI 2018 - Proceedings. pp. 284289, 2018, doi: 10.1109/ICITSI.2018.8696091.

[25] Arindy and A. Suzianti, "Developing Digital Wallet Services in Indonesia," Info M, pp. 1-6, 2020, doi: 10.1145/3429789.3429811.

[26] E. S. Soegoto and M. B. R. Sumantri, "The Influence of Digital Wallet," IOP Conference Series: Materials Science and Engineering, vol. 879, no. 1. 2020, doi: 10.1088/1757-899X/879/1/012122.

[27] Arindy and A. Suzianti, "Multi-Generation Perception towards Digital Wallet in Indonesia," ACM Int. Conf. Proceeding Ser., pp. 19-24, 2020, doi: 10.1145/3400934.3400940.

[28] R. M. W. Donald L. Amoroso, "Building a Research Model for Mobile Wallet Consumer Adoption: The Case of Mobile Suica in Japan," J. Theor. Appl. Electron. Commer. Res., vol. 7(1), pp. 94-110, 2012, 
doi: 10.4067/S0718-18762012000100008.

[29] T. Handayani and A. Novitasari, "Digital Wallet as a Transaction Media in the Community," IOP Conference Series: Materials Science and Engineering, vol. 879, no. 1. 2020, doi: 10.1088/1757899X/879/1/012001.

[30] O. Alaeddin, A. Rana, Z. Zainudin, and F. Kamarudin, "From physical to digital: Investigating consumer behaviour of switching to mobile wallet," Polish J. Manag. Stud., vol. 17, no. 2, pp. 18-30, 2018, doi: 10.17512/pjms.2018.17.2.02.

[31] K. S. Priya and V. K. M. Aragathavalli, "A study on mobile wallet services technology in digital marketing with special references to Chennai City," Int. J. Adv. Sci. Technol., vol. 29, no. 8 Special Issue, pp. 2132-2139, [Online]. Available: https://api.elsevier.com/content/abstract/scopus_id/85084573658.

[32] Ipsos, "The Evolution of The Digital Wallet: Driving The Next Wave of Growth," Evol. Digit. Wallet Driv. Next Wave Growth, pp. 1-8, 2020, [Online]. Available: https://www.ipsos.com/en-id/ipsos-mediaconference-strategi-menang-tanpa-bakar-uang.

[33] Badan Pusat Stastistik Indonesia, "Hasil Sensus Penduduk 2020." https://www.bps.go.id/pressrelease/2021/01/21/1854/hasil-sensus-penduduk-2020.html (accessed Jun. $16,2021)$.

[34] "The Generation Guide - Millennials, Gen X, Y, Z and Baby Boomers," 2015. http://fourhooks.com/marketing/the-generation-guide-millennials-gen-X-y-Z-and-baby-boomersart5910718593/.

[35] D. H. Jayani, “Transaksi Uang Elektronik Melonjak 209,8\% pada 2018.," 2019. https://databoks.katadata.co.id/datapublish/2019/09/23/transaksi-uang-elektronik-melonjak-2098-pada2018 (accessed Jun. 18, 2021).

[36] Bank Indonesia, "Bank Indonesia Merancang Gerakan Nasional Non Tunai," 2014. https://www.bi.go.id/id/ruang-media/siaran-pers/pages/sp_165814.aspx (accessed Jun. 19, 2021).

[37] C. G. Asmara, "BI : Indonesia Akan Menuju Cashless Society Dalam Waktu Dekat," 2018. https://www.cnbcindonesia.com/tech/20180208165650-37-3875/bi-indonesia-akan-menuju-cashlesssociety-dalam-waktu-dekat (accessed Jun. 19, 2021).

[38] Bank Indonesia, "Statistik Peredaran Jumlah Uang Elektronik Indonesia," 2021. https://www.bi.go.id/id/statistik/ekonomi-keuangan/ssp/uang-elektronik-jumlah.aspx (accessed Jun. 19, 2021).

[39] F. Hidranto, "E-Wallet Kian Tebal di Tengah Pandemi," 2020. https://indonesia.go.id/narasi/indonesiadalam-angka/ekonomi/e-wallet-kian-tebal-di-tengah-pandemi (accessed Jun. 17, 2021).

[40] F. Juliani, "POSITIONING UANG ELEKTRONIK BERDASARKAN PERCEPTUAL MAPPING (Studi Deskriptif Positioning OVO, GoPay, DANA dan LinkAja di Yogyakarta),” 2020.

[41] Arindy and A. Suzianti, "Multi-Generation Perception towards Digital Wallet in Indonesia," ACM International Conference Proceeding Series. pp. 19-24, 2020, doi: 10.1145/3400934.3400940.

[42] K. Weiss, "Mobile payments, digital wallets and tunnel vision," Biometric Technol. Today, vol. 2011, no. 9, pp. 8-9, 2011, doi: 10.1016/S0969-4765(11)70171-0.

[43] S. Sukaris, W. Renedi, M. A. Rizqi, and B. Pristyadi, "Usage Behavior on Digital Wallet: Perspective of the Theory of Unification of Acceptance and Use of Technology Models," Journal of Physics: Conference Series, vol. 1764, no. 1. 2021, doi: 10.1088/1742-6596/1764/1/012071. 